\title{
THE DARK SIDE OF TURKEY-BULGARIA ROUTE*
}

\author{
Süleyman KÖKSAL**
}

\begin{abstract}
Illegal affairs and dark relationships can always be encountered in any place. International links and officials can also be seen in these illegal affairs. When the communists came to power in Bulgaria in 1944, there were a significant minority of Turks. Refugee Turks arrived in the following years and some Turks from Turkey began to participate in illegal affairs in Bulgaria. The cooperation in the underground worlds of Bulgaria and Turkey, which are at opposite ends of the cold war period, is remarkable. Why do those who participate in illegal affairs in Turkey flee to Bulgaria or other Balkan countries? In this study, illegal affairs and dark relations in Turkey and Bulgaria has been discussed. Turks are the most important ethnic minority in Bulgaria. However, Bulgaria allowed Turks from Turkey involved in illegal affairs to enter the country. At the same time, black propaganda was made in the publications of the Communist Party. It was aimed to create chaos in Turkey's internal and foreign policy. A negative perception of Turkey was formed. Turks carried on their illegal affairs and dark relations after the communist period. Bulgaria is a crucial exit point between east and west in the arms and drug trafficking. Official confessions made in Bulgaria after the communist period give clues about illegal affairs and the system of dark relations.
\end{abstract}

Keywords: Bulgaria, Turkey, Illegal Affairs, Dark Relations, Smuggling.

\section{TÜRKIYY-BULGARISTAN GÜZERGÂHININ KARANLIK TARAFI}

ÖZ

Yasadışı işler ve karanlık ilişkiler her yerde ve her zaman karşımıza çıkabilir. Bu yasadışı işlerde uluslararası bağlantılar ve resmi görevliler de görülebilir. 1944 yılında komünistler Bulgaristan'da iktidara geldiklerinde önemli bir Türk azınlığg vardı. İlerleyen yıllarda mülteci Türkler geldi. Türkiye'den bazı Türkler de Bulgaristan'da yasadışı işler yapmaya başladılar. Soğuk savaş döneminin zıt uçlarında yeralan Bulgaristan ve Türkiyenin yeraltı dünyalarındaki işbirliği dikkat çekicidir. Türkiye'de yasadışı işlere karışanlar neden Bulgaristan'a ya da diğer Balkan ülkelerine kaçıyor? Bu çalışmada Türkiye ve Bulgaristan'daki yasadışı ilişkiler ve karanlık ilişkiler ele alınmıştır. Türkler, Bulgaristan'daki en önemli etnik azınlıktır. Ancak Bulgaristan, Türkiye'den yasadışı faaliyetlerde bulunan Türklerin ülkeye girişine izin vermektedir. Aynı zamanda Komünist Parti’nin yayınlarında kara propaganda yapılarak Türkiye'nin iç ve dış politikasında kaos yaratılmak istenmiştir. Türkiye hakkında olumsuz bir algı oluşturulmuştur. Türkler, komünist dönemden sonra da yasadışı işlerini ve karanlık ilişkilerini sürdürdüler. Bulgaristan, silah ve uyuşturucu kaçakçılığında doğu ile batı arasında önemli bir çıkış noktasıdır. Bulgaristan'da komünist dönemden sonra yapılan resmi itiraflar, yasadışı işler ve karanlık ilişkilerin sistemi hakkında ipuçları vermektedir.

Anahtar Kelimeler: Bulgaristan, Türkiye, Yasadışı İşler, Karanlık İlişkiler, Kaçakçılık.

Atıf: KÖKSAL, S. (2021). “Türkiye-Bulgaristan Güzergâhının Karanlık Tarafı”, İMGELEM, 5 (9): 349-365.

Citation: KÖKSAL, S. (2021). “The Dark Side of Turkey-Bulgaria Route”, IMGELEM, 5 (9): 349-365.

Başvuru / Received: 16 Eylül / September 2021.

Kabul / Accepted: 13 Kasim / November 2021.

Derleme Makale / Review Article.

\section{INTRODUCTION}

When we look at the world map, we see Turkey standing like a bridge at the junction point in the middle of three continents. Bulgaria is also Turkey's gateway to Europe. Bulgaria like other Balkan countries, emerged with the disintegration of the Ottoman Empire, which ruled on three continents. There is a significant Turkish population in the Balkans. Turks

\footnotetext{
* This study is based on Author's PhD thesis.

** PhD., Karadeniz Technical University, Department of Foreign Languages, E-mail: skoksal@ ktu.edu.tr, ORCID Number: 0000-0002-0514-9256
} 
emerge as a vital element of internal and foreign policy in Bulgaria. Every Bulgarian administration attempted to assimilate Turks and forced them to migrate through pressure and exile. With communism in 1944, positive steps toward minorities were taken at first in Bulgaria, but then the pressure on minorities increased.

Relations between Bulgaria, a member of the Eastern bloc, and Turkey, which acts with Western countries, are not good during this period known as the Cold War. Bulgaria is engaged in various activities towards its neighbor Turkey, the Bulgarian Turks and the Turks of Turkey. There are also refugee Turks in Bulgaria who fled from Turkey and believed in communism. As in all of the Eastern bloc countries, Bulgaria is a country where strict controls are made as required by the regime. However, it is also a country where many Turks from Turkey conduct illegal affairs. These Turks have close ties with Bulgarian officials. International events occur in this system of dark relations that have an impact on Turkey's internal and foreign policies. According to the Bulgarians, the Pope's assassination demonstrates that Turkish nationalists are terrorists and murderers who serve imperialism. Illegal relations and activities of the Turks continued for a long time also in the post-communist multi-party democracy period in Bulgaria. Drug trafficking, arms trafficking and illegal luxury vehicle trade were just a few of these activities. The visit of the terrorist chief Abdullah Öcalan to Bulgaria and the terrorist organization PKK's (Partiya Karkeren Kurdistan) use of the route to Bulgaria demonstrate the different dimensions of the system of dark relations. Who benefits from this dark relationships? How are these relations reflected and reacted to society?

The effects of the events mentioned above on the stability of the region's geography are very important. It is for the benefit of the people of the region to investigate the inside of these events and reveal the facts. The need for research was made in order to confirm the view of the people of the region on these issues. It is seen that extreme speculations were made in the events described and the facts were distorted. Some facts need to be uncovered and clarified. In this study, field research in Bulgaria and literature review in different libraries in Bulgaria were conducted as a method. However, some archival sources in Bulgaria could not be accessed by saying that they are prohibited. The publications in Turkey were also used. The study, whose content analysis was carried out, was updated with some additions and presented to the scientific world. This study is the result of a qualitative research. The confessions used in this study and some examples given may show that the research is accurate. 


\section{Süleyman KÖKSAL}

The clues of this system of dark relations can be seen in the media organs of the Bulgarian Communist Party, post-communist Bulgarian publications and publications in Turkey. Bulgaria's EU membership and approach to the Western world have made dark relations and illegal affairs more difficult and have shifted to other geographies.

\section{Bulgarian Turks and Their Population}

According to the census conducted in 1878, Bulgarians are in majority in Tarnova, Vidin and Sofia and Turks in other regions. However, the Turkish population is decreasing with migration. In 1914, the Turkish population was 885,000. Despite the migrations, the Turkish population is higher in some regions than the Bulgarians. In the statistics of 1934, it was seen that Turks were the majority in some regions (Keskioğlu 1985: 25, 26). According to some Bulgarian Turkish journalists, there were 1,300,000 Turks in Bulgaria in 1943 (Başbakanlık Cumhuriyet Arşivi 1943). In 1944, when the Russian troops entered Bulgaria, the communists took power. The communist regime, which started a new era, sent positive messages to every group of the country and asked for their support. The most important group was the Turks. They were also promised to get their rights. They were said to be religiously free and able to practice their faith freely. However, a few years later, Turkish schools were nationalized. The Turkish peasants' lands were taken under the guise of cooperatives. Pressures and intimidation began. Meanwhile, some Turks had immigrated to Turkey. The number of Turks attempting to migrate was also gradually increasing. These developments prompted the communist administration. For a long time, Turks did not immigrate, which increased the Turkish population. These were supposed to be removed from Bulgaria. On August 10, 1950, Bulgaria presented a note to Turkey. The perception of immigration for Bulgarian Turks was formed both before and after this date. Bulgaria wanted hundreds of thousands of Turks to be admitted to Turkey within three months. The only option of the Turks in the face of these pressures was to emigrate (Başbakanlık Cumhuriyet Arşivi 1946). So they migrated once more again.

The actual number of Turks in the census in Bulgaria is not given correctly. In 1948, in addition to official figures, Bulgarian Turks also made researches the Turkish population in their region. According to the population determination made by the students of the Turkish School 'Nüvvab', the Turks are around 1,500,000. In 1965, another study was carried out by the 'Bulgarian Turkish Youth Organizations Association'. Accordingly, there are 2,200,000 Turks. In the same year, the 'Bulgarian Statistical Institute' lowered the number of Turks by one-third, giving it 800,000. Confidential information received from Bulgarians working in this 
institution confirms the determination of the Turks. It was understood that the figure is 2,225,000. Ahmet Şerif Şerefli, one of the Turkish intellectuals in Bulgaria, stated that the population of Bulgaria, which was 9 million in 1989, fell to 7 million due to immigration, of which 4 million 500 thousand were Christians and 2 million 500 thousand were Muslims (Şerefli 2002: XX, XXI). From the establishment of the Republic of Turkey in 1923 until 1980, immigration from Bulgaria to Turkey continued intermittently. In this period, around 500 thousand Bulgarian Turks came to Turkey (Şimşir 1992: 65).

On November 9, 1989, the 'Berlin Wall' barrier between the two of Germany was lifted. The Eastern bloc started to dissolve. Travel and immigration were allowed. On January 14, the wall began to collapse. On November 10, 1989, Todor Jivkov was overthrown in Bulgaria and the period of multi-party democracy started. About six months ago, tensions between Turkey and Bulgaria reached their peak. Because the persecution of Turks in Bulgaria had reached a climax. The Prime Minister of the Republic of Turkey Turgut Özal said, "We can take all the Bulgarian Turks". Hundreds of thousands of Bulgarian Turks piled up at the Kapıkule border gate to immigrate to Turkey. The number of people coming from Bulgaria in the summer of 1989 exceeded 300 thousand (Ayın Tarihi 1989: 4). On August 21, 1989, Turkey closed its border to those coming from Bulgaria. Turgut Özal stated that the decision was taken to close the border to attract Todor Jivkov to the table of agreement (Ayın Tarihi 1989: 1).

Assimilation policies were applied to the Turkish minority in Bulgaria before communism. It was thought that Turkey supported the Bulgarian Turks. The wish to do with all these developments is as follows; it was to create a negative perception of Turks and Turkey towards the aims of the Bulgarians. Communist parties in socialist countries have always taken the Soviets as a sample in their ideology, organization and activities. The Soviet state was the model of the future (Jelavich 2006: 205). The policies implemented in Bulgaria were also an indication that the Soviets were taken as a model and the communist rulers in Bulgaria imitated the Soviet Russians. During the period of the regime, the influence of the Russians was clearly seen. The communists, who seized power, pursued a policy strictly adhering to the principles of nationality and Slavicism, with the directive of Moscow, and continued their oppression on the Turks from where the previous administration left off (Başbakanlık Cumhuriyet Arşivi 1946).

Turks from Turkey began to be seen in Bulgaria during the communist period. Some of them had been pressured for having defended communist ideology and had gone to Bulgaria. 


\section{Süleyman KÖKSAL}

Some Turks from Turkey were also engaged in illegal affairs. Bulgaria is located on a vital transit route. The Turkish press and publications of the communist regime are used for perception. Refugee Turks are also the polemicists of the communist regime with their writings. In dictatorial regimes where rulers have weaknesses, the people are directed from a single center by the publications of the communist party, since there is no freedom of the press.

\section{Turks from Turkey in Bulgaria}

While the Ottoman state was falling apart, there was a national struggle in Anatolia. Various groups wanted to be effective in this struggle and have a right in the administration of the new state to be established. Communists were one of these groups. A congress was held in Baku, Azerbaijan with the participation of a significant portion of those who were influenced by the ideas of communism. It was decided to unite all communist groups and organizations in Turkey and Russia under the umbrella of the Communist Party of Turkey (TKP). In addition, it was asked to support the national movement in Turkey. It was accepted that the TKP should be transferred to Anatolia in order to establish the rule of workers and peasants in Turkey and they also wanted to instill the idea of communism. In congress, the election of the TKP Central Committee was also made. TKP was established on 15 September 1920 in Baku, outside of Turkey. Mustafa Suphi was elected as the Head of the Central Committee (Aslan 1997: 241244).

In the confrontation during the cold war, Bulgaria took part in the Eastern bloc led by the Soviet Union, and Turkey in the Western bloc led by the United States. The Soviet Union had plans for Turkey. It supported communist activities in Turkey. Meanwhile, there were pressures and arrests of communists in Turkey. Communist thinkers were going abroad in different ways. Some wanted to go illegally. One of them was Sabahattin Ali, a Turkish intellectual killed at the border in March 1948 while trying to escape to Bulgaria.

Bulgaria has become a country where those fleeing from Turkey take shelter due to the pressure of ideas. It has also been one of the vital external centers of the TKP. A group of members of the TKP operating in Bulgaria was formed. TKP General Secretary and Russians supported and followed up the activities in Sofia. TKP members in Sofia have important roles in communist activities in European countries. Meanwhile, Turks who are refugees are forced to serve in the country where they took refuge. Tuğrul Deliorman, a communist refugee and has served communism for years, has occasionally participated in discussions in the TKP, where internal conflicts were experienced. He had regrets. But he tried not to reflect them. But one 
day: "A refugee means a lackey." he confessed to the situation they were in (Alper 1999: 398).

Bulgaria has an important position in terms of TKP. As it is on the way to transition to European countries, many socialist/communist-minded people in Turkey yearn for it. Those who find the opportunity go to Bulgaria. However, not all Turks who went to Bulgaria could get what they wanted in an ideological sense. Many Turks have even disappeared within the borders of Bulgaria. Fatma Yalçın and Savaş Üstüngel, one of the leaders of the TKP, also were imprisoned with some Bulgarian Turks. They had a love for their homeland (Turkey). Perhaps because of their love, they both died in a mystery. They were quietly buried (Şerefli 1990: 223). Unknown perpetrators were regarded as normal in repressive regimes. No one could find the cause of death of anyone, nor dared to find it.

One of the Bulgarian Turks, İshak Raşid, who worked in the media organs of the Bulgarian Communist Party, 'Halk Gençliği Newspaper' and 'Radio Bulgaria', took refuge in Turkey with his family. When İshak Raşit was in Bulgaria, he hated communism and showed his feelings. He was using the words effectively. He worked as a literature teacher in Turkey. He tried to express the experiences of the Bulgarian Turks at every opportunity. The Bulgarian administration was uncomfortable with this situation. For this purpose, journalist Ahmet İlyazov and a team were sent from Bulgaria to Istanbul in 1982 to kill İshak Raşid. İshak Raşid did not want to meet, knowing that the people who came to him did not have good intentions. However, inexplicably, he was found dead in his home (Şerefli 2006: 30, 31). Communist rule in Bulgaria had dark relations. Those who did not serve this system of dark relations, those who opposed it, were mysteriously disappeared.

\section{Turks and Dark Relationships}

During the communist period, there were Turkish drug traffickers in Bulgarian prisons (Şerefli 1990: 299). In a regime with frequent controls, illegal activities without the knowledge of the security forces bring to mind that these events are under the surveillance of the state. Before the 1970s, 'city surveillance cameras technology' was used in Bulgaria. Security in this country is made with the advanced technology of that period. At the same time, this technology emphasizes that people are taken care of as an element of pressure (Merkez İzliyor 1969).

The visit of a foreign citizen to Bulgaria or other Eastern bloc countries is closely monitored from beginning to end. At the same time, the citizens of this country travel under strict control. Minority Turks in Bulgaria are potential power. Turks are opponents of the regime. It is thought-provoking for citizens of Turkish origin involved in many illegal activities 


\section{Süleyman KÖKSAL}

to do business in a communist country. During the communist period, Bulgaria was involved in many international smuggling incidents (Tata 1993: 114).

Armenians smuggle drugs and weapons in connection with terrorist organizations. They have important roles in the route from the Middle East to Western countries (Somer 1984: 22, 23). Syrian national M. Akil Çubukçı was detained in Turkey in the 1970s on charges of smuggling weapons and bullets through Bulgaria. M. Akil Çubukçı explained in detail the smuggling he has been doing since the 1960s. He also explained his connections in Turkey. The inner circle of such smuggling incidents; M. Akil Çubukçı and Garabet Serkis Abriyan of Armenian origin. In the case where M. Akil Çubukçı and Garabet Serkis Abriyan were tried, Abuzer Uğurlu, one of the important names of the Turkish underground world, was also tried. Abuzer Uğurlu gave his address as Arh Milanov Street No: 18 Sofia, Bulgaria (Mumcu 2011: $53)$.

Abuzer Uğurlu is someone who fled to Sofia and then to Munich, Germany in order not to be arrested for his smuggling in Turkey. Abuzer Uğurlu lived illegally in Munich and Sofia until 1974. Seven kilograms of cocaine sent from Sofia to Abuzer Uğurlu in 1995 were seized at the Turkish border. Mehmet Eymür, one of the former heads of the National Intelligence Organization (MITT), announced that Abuzer Uğurlu was first used by the MIT and then by the Bulgarian secret service and the Soviets as the chief agent. It has been tried to give the impression that Abuzer Uğurlu and another famous name Bekir Çelenk are connected with some of the 'Idealists' in Turkey. This perception was deliberately made by Bulgarians and Soviets. Thus, it was aimed to confuse the various crimes committed, including the assassination of the Pope. If M. Ali Ağca had been successful in the assassination of the Pope, the Christians would have turned against Turkey. The 'Idealists/Nationalists', who were abroad, would have been the number one target of the security forces of Western countries. Bekir Çelenk smuggled arms between Germany and Bulgaria between 1966 and 1969. He returned to Turkey by taking advantage of the amnesty issued in 1974. He went abroad after the military coup of 12 September 1980. When Bekir Çelenk came to Bulgaria after the assassination of the Pope, he was arrested and sentenced to 31 months in this country. Bekir Çelenk states that he knows Abuzer Uğurlu from Sofia. Another interesting event was that these two names fled to Sofia from coffee smuggling in the 1960s (Mercan 2001: 26-28). One of the important centers of Bekir Çelenk was Sofia. He had versatile relations with Bulgarian official authorities and his relationship with the Armenians was remarkable (Mumcu 2002: 77, 78). 
In 1967, 1070 submachine guns, 400 guns and many bullets were seized in Trabzon's Sürmene district. These were sent from Varna, the port city of Bulgaria, by Şaban Vezir, who were living in Sofia and managing arms smuggling here (Mumcu 1981: 83). Şaban Vezir is a Syrian national. He had many adventures in Turkey. However, this famous smuggler was protected by some people who had important positions (Mumcu 2002: 77).

Erhan Kandemir, one of the Turkish hijackers who smuggled a plane from Turkey to Bulgaria during the communist period, took refuge in Bulgaria and worked in many jobs. He met some members of the Turkish and Kurdish underworld who were staying in a hotel in Sofia. After contacting them, he visited the communist refugee Turks in Sofia and stated that he wanted to benefit from the opportunities of the business by showing the gold and silver bars next to them (Alper 1999: 466). As can be seen from these events, the communist regime turns a blind eye to the questionable deeds of these people coming from Turkey.

Smuggled weapons were caught in Tuzla, Istanbul in 1974. In the researches, it was determined that weapons were brought from Bulgaria. These weapons belonged to Avni Karadurmuş, known as 'Yellow Avni' in the underworld. Avni Karadurmuş changed his surname to Musullulu before fleeing to Bulgaria in 1980. Avni Karadurmuş had a close commercial relationship with the state company 'Kintex' in Bulgaria. Smuggled weapons brought from Bulgaria to Turkey were sold by Avni Karadurmuş to right and left political groups. Weapons were used in political murders that resounded across the country (Mumcu 2000: 91, 92). Another incident occurred in June 1977. A Cyprus-flagged ship was caught by Turkish customs while passing through the Bosphorus with weapons loaded by the state company 'Kintex' from the Bulgarian port of Burgas (Mumcu 2011: 167-169).

Especially during the 'Cold War' period, some states began to use terrorism for their own interests and to establish relations with terrorist organizations. Thus, the phenomenon of state-sponsored international terrorism emerged. The state that supports terrorism provokes international events, creates an atmosphere of fear in the target country, demoralizes the people and forces them to consume the country's material resources. The target country is desired to be weakened economically, politically and militarily. This is planned by supporting terrorism as a tool of foreign policy (Kedikli 2013: 122,123).

The Soviet regime model is applied in Bulgaria. It should not be thought that Bulgaria had dark relations, unaware of the Soviet Union, which was the leader of the Eastern bloc, in both its internal and foreign policy. It must be considered that the Soviets directed the countries 
in the Balkans against Turkey. According to A. Saylgan, the Soviets are very careful about their games. They even provoke internal quarrels of the parties of their target countries. The Soviets used Bulgaria in provoking the increasing anarchy in Turkey since the 1970s. As in the case of the Pope, even the weapons to be used by some adventurous (Turkish) nationalists (!) are pre-selected. The Soviets asked, and the Bulgarian Dimıtır Şişmanov wrote a book called 'Gunshots in the Bosphorus'. Thus, anarchy in Turkey was extolled. No other explanation is possible (Sayılgan 2009: 527).

Terrorist incidents in Turkey have caused an international concern along with M. Ali A ğca. M. Ali A ğca was caught after shooting the Pope on 13 May 1981 and made a statement at the Roman prosecutor's office. In his statement, he explained that he moved to Bulgaria between 10-15 July in 1980 and stayed in different hotels in Sofia for 40-50 days. There was Bekir Çelenk in one of these hotels. He was using a fake ID issued in the name of Necati Çelik. Ağca explained that during his stay in Sofia, he met some people connected with illegal affairs and passed to Belgrade issuing fake passports (Mumcu 1981: 46, 47). A $\breve{g} c a$ also stated that he received training from Bulgarian experts in a camp in Syria (Ağca: Suriye'de 1985).

The world press wrote that the Bulgarians were behind M. Ali Ağca's shooting on the Pope, which concerns Turks and creates an international agenda. Bulgaria was unexpectedly drawn into this assassination. The Bulgarians claimed that right-wing fascists were behind Ağca, who shot the Pope. Two years after the Pope was shot, a series of articles was published in the media organ of the Communist Party of Bulgaria (BKP) 'Yeni Iş1k Newspaper'. In these articles, it was written that Ağca was a fascist member of the 'Gray Wolves' organization. It was also stated that Ağca was involved in murders other than the murder of Abdi İpekçi in Turkey. The author of the article, Yona Andronov, researched in Bulgaria, Italy and Turkey. He met with many people such as Bekir Çelenk in Bulgaria, Uğur Mumcu and Abdi İpekçi's wife Sibel İpekçi in Turkey. In the article series, it was explained that the Bulgarians or the socialist world did not have a hand in M. Ali Ağca's shooting on the Pope. It was stated that A ğca stayed in Sofia before shooting the Pope, but who he met and what he did during this time were not disclosed (Andronov 1983). After a few years, the agenda about Ağca was formed again. Based on a police officier from Germany, the Bulgarians said that Ağca was linked to the extreme rightist, namely fascists, in Turkey and Germany. It was also stated that Ağca was linked to the Israeli intelligence agency and those who pulled the trigger were the collaborators of the imperialists (İbrahimov 1981). 
The Bulgarian press continued to react to the news that the Bulgarians had a hand in $\mathrm{M}$. Ali Ağca's shooting on the Pope. Comments were made in the Bulgarian press based on information from a book published in Germany. The Bulgarian press stated that Western country newspapers and American intelligence were deliberately libeling. And the press in Bulgaria wrote that there were no Bulgarians and the Soviet Intelligence Service KGB behind A ğca. It was aimed to restart the cold war. For this purpose, Ağca was used. The Pope was shot as a result of an assassination stemming from the relations between Turkish neo-fascists, called 'Gray Wolves', and neo-fascists in Germany. Ağca was a murderer under the command of the 'Gray Wolves' (Gerçek Gizlenemez! 1985). Socialist/communist publications of different countries also supported the Bulgarians. In these reports, it was stated that the news that there were three Bulgarian citizens behind the shooting of the Pope was unreal (Yalan ve Ifftira 1985). Bulgarians try to show that socialists are innocent by blaming the nationalists in Turkey. A book was published in Bulgaria for this purpose. This book claims that Bulgarians are unaffiliated with terrorism. International connections of M. Ali Ağca and Turkish nationalists were mentioned. ${ }^{1}$ The facts were distorted in these publications by reporting to Bulgarian Turks that Turkey is a troubled country in chaos.

Hikmet Sevcan is another important smuggler who fled to Bulgaria after the 12 September 1980 coup. He is someone who was on the search list by Interpol as a drug, gun and gold smuggler. He had a partnership with the state company 'Kintex' in Bulgaria. He owned many companies and was promoted as a respected businessman. Hikmet Sevcan is said to have protected Alaattin Çakıcı, a Turkish underworld bully, in Bulgaria (Aydın 1998). It is understood that Bulgaria was one of the main transition points of drug and arms smuggling during the communist period and played an important role. Meanwhile, Colombia, one of the centers of the world drug market, has close relations with Bulgaria. These relations demonstrate that Bulgaria is an important component of the system of dark relations in the region (Douglas \& Potes 1984: 41-44). Ships of the Tamil Tigers terrorist organization stop by the ports of Bulgaria, Greece and some European countries and obtain weapons through non-governmental organizations, terrorist and organized crime organizations (Bal \& Özeren 2010: 189). Those who smuggle drugs and weapons may not have any ideological aims. However, it is inevitable for them to establish relations with terrorist groups in terms of their interests in the marketing of their goods (Somer 1984: 20).

\footnotetext{
${ }^{1}$ See for detailed information Krasimir Drumev, İftiranın Karşısında Gerçek, Sofia Pres, Sofia, n.d., (Possibly published in 1985).
} 
In Bulgaria, where illegal affairs such as arms smuggling and drug smuggling are carried out internationally, many Turkish citizens are also involved in these works. Turkey's internal and foreign policies have been harmed as a result of these events. The intention of those who seek profit from these businesses is obvious. There is also a dangerous situation in terms of the security of the region. The weaknesses of the security forces of Turkey and Bulgaria are obvious. These actions damage both countries. Meanwhile, a pro-Kurdish formation in Bulgaria emerges during the post-communist period. While the PKK is said to have a pleasant working atmosphere in Bulgaria, there is a long-standing relationship with the activities of the terrorist organization.

The PKK terrorist organization has been involved in many illegal activities since its establishment. The organization initially received commissions from drug activities. In the following years, he took part in these activities himself due to the high economic return. The organizational area of the organization in the region stretching from the Middle East to Europe is the Balkan route, which is one of the most important drug trafficking routes in the world. Turkey borders the "golden crescent" region (Pakistan, Afghanistan, Iran) where drugs are produced, transported and marketed illegally. Some of the drugs reaching European markets are transported through Turkey. The PKK plays an active role in this marketing and takes an important share (Alkan 2008: 142, 143). The price of the drug increases astronomically as you get closer to the areas of use from the production areas and the longer the trade route. For example, a unit of drugs costs 2,2 USD in Iran, 13,5 USD in Germany and 158,5 USD in the USA (Somer 1984: 20).

The terrorist chief, Abdullah Öcalan, was living in Syria before he was captured in February 1999 and brought to Turkey. It is stated that Öcalan went to different countries in Europe from time to time during these periods. Bulgaria is one of these countries. When Öcalan explained his relations with Bulgaria, he said that they have an office in the city center of Sofia. He also announced that he stayed in Bulgaria in 1982 and 1987 for the support of Bulgaria for the fight of the terrorist organization PKK against Turkey. According to Şamil Tayyar, Bulgaria has become a strategic country in terms of PKK's arms supply. Russian weapons have been delivered to the PKK through this country. Bulgaria is also an important drug-trafficking route for the PKK. The communist regime also used its relationship with the PKK as a tool to exert pressure on the Turks (Tayyar 2011: 292). The Ministry of Internal Affairs of Bulgaria, which is known to have relations with the PKK and supports members of the terrorist organization, reported that there are no PKK training camps in Bulgaria. It has been also stated that it is not 
possible for Bulgaria to support terrorist organizations (Bizde PKK 1997). However, even in the early 2000s, it was known that there was an office of the PKK on Stamboluski Street in Sofia and members of the organization gathered here. The PKK received logistical support, campsite and training support from many countries, including Bulgaria and some other European countries (Bal \& Özeren 2010: 90).

The first years of the multi-party democracy period in Bulgaria passed with uncertainty. This situation paved the way for some people in important positions in the communist regime to commit illegal acts. Many people took advantage of the transition period and tried to expand their money-making systems during this period. Bulgarian Prime Minister Ivan Kostov warned the public and asked not to pay tribute to the mafia. Explaining that 60 percent of the state's internal revenue is under the control of the mafia, the prime minister said that they would save Bulgaria from the image of the mafia state (Mafyaya haraç 1997).

Halis Okan is one of the Turkish refugees forced to flee to Bulgaria due to his communist beliefs. He served a prison sentence during the communist period. However, despite this, he achieved a luxurious life that very few people had. Halis Okan became one of the richest people in Bulgaria during the post-communist democracy period. He had a political party, seven newspapers, three foundations, banks, hotels, shops, houses and a farm before his death in the 2000s. His antique collection was exhibited in a state gallery. The police chiefs of the communist dictator Todor Zhivkov were at his disposal and served him. It is said that Halis Okan came to this situation by laundering the money of the communist administrators. During the period of democracy, Halis Okan was also mentioned with a new religion supported by socialism. Halis Okan unified Marx, Jesus and Muhammad, and created a new religion. Halis Okan claimed that he had received revelation for 14 years and tried to spread this religion from the Balkans to the whole world (Aydin 1992-1993: 18-24).

Since the illegal affairs in Bulgaria are known, this country has been especially popular with some Turkish citizens during the multi-party democracy period. Another name of the Turkish underground world, Kürşat Yılmaz, also entered Bulgaria illegally and was caught during this period. It is remarkable that Reni Tzanova, who defended the oppressive dictator of the communist period, Todor Jivkov, was the advocate of Kürşat Y1lmaz (Aydın 1998). Many businessmen and well-known figures have been spotted in Bulgaria, where they have entered the country illegally. One of them is Süleyman Demirel's nephew, one of Turkey's former presidents. Murat Demirel, banned from going abroad, tried to enter Bulgaria illegally by sea 


\section{Süleyman KÖKSAL}

from Turkey on December 31, 2004. There was also a large amount of money with him. When the current Bulgarian Prime Minister Boyko Borisov was the Chief of Police, Murat Demirel was apprehended and handed over to the Turkish authorities by Borisov himself (Tunca and Gün 2005). It should not be forgotten that Bulgaria is a country with easy access through such roads.

Security flaws, the democratic process of the country and dark connections appear as illegal activities in different ways. Bulgarian highways, which are a nightmare for Turks working in Europe and those traveling to European countries for various reasons, reveal yet another facet of the country's illegal activities. Events such as robbery and extortion are seen almost every day, and people are killed. Even diplomats were attacked in the 2000s. Turkish Consul Mehmet Koza, who was attacked on his way from Plovdiv to Burgas in Bulgaria, was brought to Turkey and treated (Saldırıya uğrayan 2000).

However, following the September 11 attacks, and under the pressure of Western countries, illegal activities in Bulgaria began to be taken under control. Bulgaria's attempts to become a member of NATO and the EU also tightened these controls. Bulgaria became a member of NATO in 2003 and an EU in 2007. During this period, it was observed that the citizens of Turkish and Middle Eastern origin in Sofia were cleared of their regions under the guise of commercial activity. It is seen that democracy has begun to settle in Bulgaria and the controls are being taken seriously, albeit slowly. As a result, dozens of groups against international criminal organizations were destroyed by joint operations by Turkish and Bulgarian officials (Türk meslektaşlarımızla 2005). There are actually police chiefs who fight against illegal work. These are the nightmare of the underworld. But the strength of these police chiefs is not enough to fight. The system either liquidates them, ostracises them, or retires them. Those who keep up with the system get a share of the pie and are promoted (Yurdakul 2012: 128).

Now there is a period of multi-party democracy in Bulgaria. Some of the illegal work done during the communist period have been documented by official sources. State officials announced that M. Ali Ağca stayed in Bulgaria for 37 days in 1980, shortly before the conspiracy of the Pope. M. Ali Ağca was registered as a citizen of India and used the name Yogender Singh, according to the information given by the General Secretary of the Interior Ministry, General Boyko Borisov. Ağca's activities during his stay in Bulgaria were expressed as 'inexplicable' (Ağca'nın Hindu 2005). Meanwhile, Boyko Borisov became prime minister a 
few years later. And Borisov continued his duty until the parliamentary elections held on April 4, 2021. The list of bureaucrats who were agents during the communist period was also published. It has been announced that 191 diplomats, including 33 ambassadors, 8 charge d'affaires, and 4 consuls, acted as agents on behalf of their country during the communist period. Prime Minister Boyko Borisov said those still active would be dismissed (Süleyman 2010).

Bulgaria is the first country where the Turkish underworld's famous names flee illegally. Bulgaria is also known for being the source of smuggled cigarettes before and after Turkey's 1980 coup. This system of dark relationships, which existed both during and after communism, made money from drugs, weapons, and later, illegal luxury vehicles. In addition to the well-known names of the underground world, Turks who smuggle the money of those they have defrauded through the illegal cryptocurrency trade are on the agenda these days. In connection with people in the system of dark relations, these well-known names and cryptocurrency cheaters have fled to the Balkan countries once again. However, since Bulgaria joined the EU, the legal understanding has changed, external pressures have increased and illegal affairs have become more difficult. Thus people in dark relationships have turned to other Balkan countries such as Macedonia, Kosovo, Montenegro and Albania. For example, Sedat Peker, one of the leaders of organized crime organizations in Turkey, has been to different Balkan countries for more than a year. Nowadays, Peker admits the dark relationships he has experienced in the past with his internet broadcasts from Dubai and threatens top state administrators.

As a result of the developments, an anti-mafia party was founded in Bulgaria. It is called 'Get Up! Mafia Out!'. The parliamentary elections held on April 4, 2021, had fourteen deputies. $^{2}$ The public reaction to the activities that disrupt the building blocks of society is a positive development.

\section{CONCLUSION}

It is understood in this international system of dark relations that citizens and officials from the Eastern and Western bloc countries act in an organized manner. The organized group of people from various countries, ethnic and religious backgrounds, regimes, and government officials indicates that this system is managed globally by a higher mechanism. Or, similarly, it

\footnotetext{
${ }^{2}$ In the parliamentary elections held again on July 11, 2021, the 'Get Up! Mafia Out!' party had thirteen deputies but increased its votes even more.
} 
can be thought that there are dark power centers protected by the higher authorities of the state in countries where these relations exist. Bulgarians and Turks who lived together for five centuries under the Ottoman rule and were influenced by common cultures have known each other well. As a way of assimilating and suppressing minority Turks in Bulgaria, some elements in internal and foreign policy were used as propaganda tools. These elements are some Bulgarian Turks, refugee Turks under the roof of the TKP and some of the famous names of the Turkish underworld. The perceptions formed by these propagandistic activities were used to create chaos in Turkey's internal and foreign policy. Thus, the bond between Turkey and the Bulgarian Turks would be weakened. Being a potential opposition force, the Turks would be easily controlled and even assimilated. If necessary, the Turks would be exiled and forced to migrate.

In Bulgaria, whose economy degraded during the communist period, it was attempted to contribute to the country's economy with unregistered income through dark relations and illegal affairs. As in the study here, international system of dark relations is often seen as linked to Eastern bloc countries or dictator regimes. In such countries, dictatorial governments lack community support, and the majority are economically poor. On the other hand, measures taken with international balances and pressures yield positive results. The fields of dark relationships and illegal activities are shrinking. Dark relationships increase or decrease according to regimes and legal systems. Despite the measures and security systems taken, thieves also improve their methods. Today, dark links are made on the internet, using digital technology.

The hidden connections of the international system of dark relationships, which humanity sees as a global threat, cannot be fully clarified. Some facts are not disclosed by highlevel state officials as a 'state secret'. This situation suggests that some officials are a possible part of an international system of dark relationships engaged in illegal organized work. In Bulgaria, the sanctions imposed by the EU membership, the government's opposition to illegal affairs, and the public's reaction by supporting the anti-mafia party, narrow the range of activities for those in the international system of dark relationships. Since they cannot be at ease in Bulgaria, Turks involved in illegal affairs flee to other Balkan countries. Turks involved in illegal affairs generally prefer Balkan countries. These people can easily obtain official assurance by using their financial power and dark relationships in these countries. The reason for this must be that criminals do not believe they are safe under the rule of law. 


\section{REFERENCES}

“A ğca: Suriye'de eğitim gördük". (1985, 7 Haziran). Cumhuriyet Gazetesi.

“A ğca'nın Hindu adı kullanarak Bulgaristan' da kaldığı ortaya çıktı”. (2005, 25 Nisan-1 Mayıs). Bulgaria Zaman Gazetesi.

Alkan, N. (2008). Söz Bitmeden Terörle Mücadelede Önleme Stratejileri, Ankara: Uluslararası Stratejik Araştırmalar Kurumu.

Alper, O. R. (1999). Mülteci Komünist, İstanbul: Timaş Yayınları.

Aslan, Y. (1997). Türkiye Komünist Fırkası'nın Kuruluşu ve Mustafa Suphi, Ankara: Türk Tarih Kurumu Basımevi.

Aydın, G. (1992-1993). Bulgar Mafyasının Türk Peygamberi Kızıl Halis, Aktüel Dergisi, (78), $18-24$.

Aydın, G. (1998, 15 Eylül). Çakıcı'nın izini sürerken Hikmet Sevcan'a rastladık. Hürriyet Gazetesi.

Aydın, G. (1998, 15 Eylül). Kürşat Yılmaz’ın komünist avukatı. Hürriyet Gazetesi.

Ayın Tarihi Dergisi. (1989, 20 Ağustos). No: 4.

Ayın Tarihi Dergisi. (1989, 22 Ağustos). No: 1.

Bal, İ., Özeren, S. (2010). Dünyadan Örneklerle Terörle Mücadele, Ankara: USAK Yayınları.

Başbakanlık Cumhuriyet Arşivi. (1943, 18 Haziran). 30-10-0-0_243-645-4_1.

Başbakanlık Cumhuriyet Arşivi. (1946, 1 Ağustos). 030-0-010-000-000-243-646-6.

“Bizde PKK kampları yok”. (1997, 25 Haziran-1 Temmuz). Bulgaria Zaman Gazetesi.

Douglas, R., Potes, C. (1984). Bulgaria, Gnosticism, and the drug Mafia, EIR, 11(32), 41-44.

“Gerçek Gizlenemez!”. (1985, 5 Yanuari). Yeni Işı-Nova Svetlina Gazetesi.

İbrahimov, B. (1981, 20 Yuni). Tetiği çeken belli ya çektiren?. Yeni Işık-Nova Svetlina Gazetesi.

Jelavich, B. (2006). Balkan Tarihi 20. Yüzyıl, İstanbul: Küre Yayınları.

Kedikli, U. (2013). Uluslararası Terörizm ve Devlet Sorumluluğu, Ankara: Nobel Yayın.

Keskioğlu, O. (1985). Bulgaristan'da Türkler Tarih ve Kültür, Ankara: Kültür ve Turizm Bakanlığı Yayınları.

"Mafyaya haraç vermeyin, devlete verginizi ödeyin”. (1997, 2-8 Temmuz). Bulgaria Zaman Gazetesi.

Mercan, F. (2001). Abuzer'in En Esrarengiz Y1llar1, Aksiyon Dergisi, 348, 26-28.

“Merkez İzliyor”. (1969, 14 Ocak). Yeni Işsk Gazetesi.

Mumcu, U. (1981). Silah Kaçakçılı̆̆ı ve Terör, İstanbul: Tekin Yayınevi.

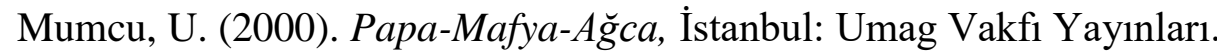

Mumcu, U. (2002). Terörsüz Özgürlük, Ankara: Umag Vakfı yayınları.

Mumcu, U. (2011). Silah Kaçakçılı̆̆ı ve Terör, Ankara: Umag Vakfı Yayınları.

“Saldırıya uğrayan Burgas konsolosu”. (2000, 21-27 Kasım). Bulgaria Zaman Gazetesi. 
Say1lgan, A. (2009). Türkiye'de Sol Hareketler, İstanbul: Doğu Kütüphanesi.

Somer, T. (1984). Ermeni Terörü ve Uyuşturucu Madde Kaçakçılığı, in Uluslararası Terörizm Sempozyumu 17-18 Nisan 1984 (19-28), Ankara: Ankara Üniversitesi Basımevi.

Süleyman, B. (2010, 20-26 Aralık). Başbakan: Ajan diplomatlarımızla vedalaşmamız gerek. Bulgaria Zaman Gazetesi.

Şerefli, A. Ş. (1990). Türk Doğduk Türk Öldük, Ankara: Kültür Bakanlığı Yayınları.

Şerefli, A. Ş. (2002). Bulgaristan'daki Türkler 1879-1989, Ankara: Kültür Bakanlığı Yayınları.

Şerefli, A. Ş. (2006). Giderayak, Ruse: Goren Dunav Vakfı Yayını.

Şimşir, B. N. (1992). Bulgaristan Türkleri ve Göç Sorunu, in Bulgaristan'da Türk Varlığı Bildiriler 7 Haziran 1985 (47-66), 3rd ed., Ankara: TTK Yayınları.

Tata, S. (1993). Türk Komünistlerinin Bulgaristan Macerası, İstanbul: Boğaziçi Yayınları.

Tayyar, Ş. (2011). Kürt Ergenekonu Derin PKK’nın Gizli Kodları, İstanbul: Timaş Yayınları.

Tunca, E., Gün, E. (2005, 10-16 Ocak). Tekneyle Bulgaristan'a kaçan Demirel yakalanıp Türkiye'ye iade edildi. Bulgaria Zaman Gazetesi.

“Türk meslektaşlarımızla onlarca organize grup çökerttik”. (2005, 31 Ocak-6 Şubat). Bulgaria Zaman Gazetesi.

"Yalan ve İftira". (1985, 12 Yanuari). Yeni Işık-Nova Svetlina Gazetesi.

Andronov, Y. (1983). Kurdun izinde. no. 87, 88, 89, 90, 91, Yeni Iş1k-Nova Svetlina Gazetesi.

Yurdakul, D. (2012). Abi Kabadayllar, Mafya ve Derin Devlet, İstanbul: Kırmızı Kedi Yayınevi. 
